\title{
PROTECTION AGAINST THE ABUSE OF ECONOMIC POWER IN BELGIUM: THE LAW OF MAY 27, 1960
}

\author{
Charlex del Marmol $\dagger$
}

AND

Marcel Fontaine $\ddagger$

\section{INTRODUCTION}

On May 27, 1960, seventy years after the passage of the Sherman Act ${ }^{1}$ in the United States, the Belgian Parliament enacted a comprehensive law against the abuse of economic power. ${ }^{2}$ The reasons for Belgium's prolonged failure to legislate on restrictive practices are intimately bound up with the structure of the nation's economy.

\section{Factors Impeding Enactment of an Antitrust Law}

At the beginning of the nineteenth century, Belgium's heavy industries-steel, coal, nonferrous metals, and glass-were among the leading ones on the European continent. These industries owed their power to the financial support of mighty "groups," such as the Société Générale de Belgique, which exerted a dominant influence on the Belgian economy until 1935. In that year the separation of "deposit banks" from "business banks," to prevent the investment of bank deposits in industry, severely diminished the economic influence of these holding companies.

In addition to heavy industry, Belgium's economy is characterized by a very large number of small enterprises, each inadequately armed to protect itself against competition, especially from foreign quarters. Their plight has been made more acute by the lowering of tariff barriers within the Common Market. The Belgian Parliament has long tried to foster "rationalization" of the nation's economy by promoting mergers and concentrations through fiscal and other

$\dagger$ Professeur Extraordinaire à la Faculté de Droit de Liège. Docteur en Droit 1932, Université de Liège; Agrégé de l'enseignement supérieur 1936.

\$ Collaborateur Scientifique du Patrimoine de l'Université de Liège. Docteur en Droit 1960, Université de Liège.

126 Stat. 209 (1890), as amended, 15 U.S.C. $\$ 1-7$ (1958).

2 The law was published in the [1960] MonITEur BELGE 4674, 5210 (the official Belgian gazette). For a more detailed commentary see DEL MARMoL, LA PROTECTION CONTRE IES ABUS DE PUISSANCE ECONOMIQUE EN DROIT BELGE, Collection scientifique de la Faculté de Droit de Liège, Université de Liège (Belgium). 
measures. Already, Royal Decree Number 62 of January 13, $1935^{3}$ - the "decree on compulsory cartels"-had enabled the stipulations of agreements between members of trade associations to be made compulsory in entire sectors of the economy. The decree resulted from the economic crisis of a time when it was thought that "confident and efficient cooperation between Belgian producers in the same branch of industry . . . had become an absolutely unavoidable necessity." *

Since 1918 Belgium's free-exchange policy (except in the field of agricultural products) has permitted foreign competitors to check the influence of local monopolies and temper the workability of cartels. This liberal trade policy, by insuring competition in most branches of the Belgian economy, deferred any felt need for antitrust legislation.

Even before the 1960 law, there were several judicial devices for controlling abuses of economic power and excessive restrictions on competition. Articles 6 and 1131 of the Civil Code empower courts to cancel contracts contrary to public policy (l'ordre public). A decree of March 17, 1791, proclaims that "any person is free to pursue whatever business or to practice whatever job, art, or handicraft he finds good . ..." That text, dating from the French Revolution and still in force in Belgium, embodies the principle of free enterprise. Although not incorporated into the Belgian Constitution, it is the basis of the nation's economic organization; and Belgian courts have frequently resorted to it as a rationale for cancelling certain agreements, especially boycott cartels, for example, in cases in which a tradesman's economic existence is threatened by a seller's refusal to deal with him. The fundamental article on tort liability in Belgitum's Civil Code ${ }^{5}$ has been applied to restraints of trade to enable victims of unfair competition to obtain damages. A 1934 decree grants competitors the right to file suit to end unfair commercial practices. ${ }^{\circ}$ Penal laws punish those who fraudulently control prices. ${ }^{7}$

\section{Postwar Developments Encouraging Antitrust Legislation}

Despite this background, three factors induced the Belgian Parliament to legislate on the abuse of economic power: the influence of the

3 [1935] Moniteur belge 229, 2 Les Codes Larcier 401 (1959) (Be1.).

4 Report by M. d'Alcantara in the Belgian House of Representatives, Annales Parlementatres, Chambre, May 18, 1960, at 3. At about the same time in the United States, the National Industrial Recovery Act, 48 Stat. 195 (1933), had authorized "codes" legalizing and even imposing cartels aimed at preventing competition which would lower prices.

5 "Tout fait quelconque de l'homme, qui canse à antrui un dommage, oblige cehui par la faute duquel il est arrivé à le réparer." CoDE CIVIL art. 1382 (Bel. 1 Larcier 1959).

${ }^{6}$ Royal Decree No. 55, Dec. 23, 1934, [1934] Moniteur belge 6851, 2 Les Codes LARCIER 358 (1959) (Bel.).

7 See CodE PENAL art. 311 (Bel. 2 Larcier 1959); Law of July 18, 1924, 2 LES Codes Larcier 423 (1959) (Bel.). 
United States, European international cooperation, and internal political developments.

\section{Influence of the United States}

At the end of World War II, the United States urged members of the United Nations to fight against practices restricting competition. ${ }^{8}$ The upshot was the UNESCO-sponsored Conference on Trade and Employment which promulgated the Havana Charter for an International Trade Organization (1948), chapter five of which was devoted to restrictive commercial practices. ${ }^{9}$ In the agreements for economic cooperation between the United States and countries benefiting from the European Recovery Program, the European governments promised to take measures to prevent restrictive commercial practices in international trade. ${ }^{10}$

\section{European International Cooperation}

The development of supranational institutions in Western Europe and the awakening spirit of a European community have had a growing influence upon the Belgian attitude toward antitrust legislation. The underlying change is embodied in several treaties, such as those creating the European Coal and Steel Community, the Community for Atomic Energy (Euratom), and, most important, the European Economic Community (Common Market) between France, West Germany, Italy, the Netherlands, Belgium, and Luxembourg. These treaties, which opened a market of 160 million people to the enterprises of the six member-nations, will undoubtedly cause economic units to adapt to the size of this market by mergers and industrial agreements. ${ }^{11}$ Insofar as this evolution impairs free competition, it will be subject to articles 65 and 66 of the Coal and Steel Community Treaty and articles 85 and 86 of the Common Market Treaty, concerning cartels and monopolies. ${ }^{12}$ Article 87 of the Common Market Treaty implies that national governments must make the necessary regulations and appoint authorities to cooperate in the application of articles 85 and 86 . The countries which

8 U.S. Dep't of State, Pub. No. 2411, Commerctal, Policy Ser. No. 79, Proposals for Expansion of World TRade and EMployment 4-5, 19 (1945).

9 U.N. Doc. No. E/Conf.2/78 at 35-38 (1948). Only that part of the Charter containing the General Agreement on Tariffs and Trade (GATT) was ratified by the number of states required to bring it into force.

10 E.g., Economic Cooperation Agreement With Italy, June 28, 1948, art. II, para. 3, 62 Stat. 2428, T.I.A.S. No. 1789.

11 See Van Themaat, Rules of Competition and Restrictive Trade Practices, in Legal Problems of the European Economic Comnunity and tHe European FreE TRADE Association 83-84 (International and Comparative Law Quarterly Supplementary Publication No. 1, 1961).

12 See also $i d$. at 84 . 
had not yet passed national antitrust laws-Belgium, Italy, and Luxembourg-were thus compelled to plan, at a minimum, their participation in antitrust action under the treaty. ${ }^{13}$ It was difficult for them not to consider passing national laws on internal restrictions of competition at the same time.

\section{Internal Political Developments}

Finally, an internal pressure toward the adoption of an antitrust law had been developing in Belgium. Once the decree of 1935 on compulsory cartels came into force, the need for a counterweight was felt. It was on the basis of the public interest (lintérêt général) that the requests of the trade associations were to be considered: the same public interest could justify the prohibition of abusive restrictions on competition. Preliminary drafts of an antitrust law were prepared as early as 1936 , but the outbreak of the war did not allow them to reach the stage of parliamentary debate.

The situation of the country after the war stimulated a fever of government control of the economy by various regulations. A bill "on the control of financial enterprises" was introduced in the Senate on November 13, 1945, by Social-Christian Senator Ronse. ${ }^{14}$ It proposed to empower the Commission Bancaire ${ }^{15}$ to exert a "watchful control on financial groups," and "to take any decision required by the public interest (l'intérêt général)," since "the influence of these financial groups on the economy of the country can . . . cause abuse." The Ronse bill was not even discussed in Parliament. In 1947, Representative Jean Duvieusart introduced another bill dealing with protection against abuses of economic power, ${ }^{18}$ but the inertia of parliamentary procedure and various events in Belgian politics delayed the enactment of an antitrust law for thirteen years.

Arguments during these years of maturation concerned chiefly the administration and scope of the proposed law. No serious disagreement as to its necessity developed. All three major political parties agreed on the proposal, but for different reasons. The Socialist party $(P S B)$, the second largest political party, and the socialist labor union (Fédération Général du Travail de Belgique) supported an antitrust law as a first, albeit insufficient, step toward complete govern-

13 Id. at 85 .

14 [1945-46] Documents Parlementaires, SEnat, No. 6. Financial enterprises are known in Belgium by the word "holding."

15 This commission performs a similar function, with regard to the issuance of securities, as the United States Securities and Exchange Commission.

16 [1946-47] Documents Pardementatres, Chambre, No. 123. 
ment control of the economy. ${ }^{17}$ The large Social-Christian party $(P S C)$ and the smaller Liberal party $(P L)$ accepted the contributions of big capitalistic enterprises to a healthy economy, but espoused public control of abusive practices to protect smaller businessmen and consumers. ${ }^{18}$ The basic choice to prohibit only the abuses of economic power, and not to forbid restrictions of competition per se, was made at the very beginning and was never questioned in the later stages. ${ }^{19}$

On December 15, 1959, the Belgian Senate passed the present antitrust law by a vote of 131-1 with seven abstentions. On May 19, 1960, the House approved, 177-3 with three abstentions.

\section{Tentative Character of the New Act}

It is important to point out the part played by the Conseil Central de l'Economie in the formulation of the statute. This Council, an advisory institution composed of an equal number of representatives of employers and labor associations, was consulted twice, in 1952 and 1958. In the course of its 1958 proceedings, business and labor repre-

17 In a report prepared for its 1956 convention, the FGTB described the grip of financial groups on the Belgian economy and expressed its claims as follows: "The problem is no longer to choose between a planned economy and a competitive economy. It is only to know who will assume leadership of the economy. Should it be left to the capitalists from whom one cannot demand or expect that the economy be led in a direction other than that of their personal interests, or should it return to the State, which represents lintérế géméral? Our answer is that private feudalities must return to the democratic order. Leadership in the economy must be exercised by the government, in the interest of the community and under its control." FÉDÉRATION Générale du Travail de Belgidue, Holdings et Democratie Economidue 216 (1956). During the House debates, a Socialist representative threw his group's support behind the bill, but underlined its weaknesses, foreseeing possible amendments in the future. Annales Pardensentaires, Chambre, May 18, 1960, at 6.

18 A Liberal representative declared: "We Liberals believe one of the most important duties of any government is to secure the defense of freedom, social and economic. The return to a perfect intercourse of free competition is an essential item in our economic program. We approve of any measures which favor true competition in the future. Everyone, including the most prominent legal minds, is ready to acknowledge that economic power and property rights must be limited. It can be stated that this bill is of liberal inspiration, which will soothe all the supporters of a free economy and personal initiative." ANNAles Parlementadres, Chamrbe, May 18, 1960, at 8. The Social-Christian view was similar: "It is not necessary to be a great economist to know that competition does not always produce the best results." Big business is necessary in some parts of the economy and its dynamic behavior is the basis of real economic progress. Nevertheless, free competition is "the most effective means of promoting the general welfare" "But since producers do not always obey the rules of the game, "legislation on restrictive agreements and abuses of economic power is . . . absolutely necessary." [1958] LA RevUe PoLITIQUE 428-30.

19 The polar theories of antitrust legislation are the "interdiction" system, which holds that all cartels should be prohibited, the philosophy prevailing in the United States, and the "abuse" system, which condemns only the harmful effects of cartels, the approach of most European anti-restrictive legislation. The debates which took place at the Havana Conference on Trade and Employment, see text accompanying notes 8-9 sipra, emphasized the differences between these theories. The conflict cropped up again in 1951 in discussions before UNESCO in which the United States asked that the legal treatment of restrictive practices in international trade be reexamined. Restrictive Business Practices, U.N. EcoSoc CouncI OFF. REc. 13th Sess., at 609-46 (E/SR.546-49) (1951). 
sentatives agreed on the fundamental items of an antitrust statute and thus contributed greatly to the almost unanimous vote for the law in both houses of Parliament. The Council stressed the fact that this law should be considered experimental, arguing that the structural changes which would take place within Belgian industry during the first years of the Common Market must not be hindered. Thus it should be possible to change the statute in later years to accord with the laws applicable in other common market nations and to respond to the evolution of economic conditions wrought by the Common Market. The experimental nature of the law was again pointed out during the parliamentary debates, a fact which indicates that even the legislature does not consider the law of May 27, 1960, as final.

\section{Scope of the New Act}

Articles 1 and 2 of the law of May 27, 1960, define its scope:

Article 1. Economic power, for purposes of this act, is the power by which a natural or legal person acting alone, or a group of these persons acting in concert, can exert within the boundaries of the Kingdom, through industrial, commercial, agricultural, or financial activities, a preponderant influence on supplying the market for commodities or capital, or on the price or quality of a given commodity or service.

Article 2. There is abuse, according to this law, when one or more persons, having economic power, harm the public interest through practices which distort or restrict the normal course of competition or which hinder either the economic liberty of producers, distributors, or consumers, or the development of production or exchanges.

\section{Preponderant Economic Power}

\section{Concept}

There is economic power when a natural or legal person, or group of such persons, exerts a preponderant influence on a given market. Economic power as such remains free to act, but if its influence becomes preponderant and is misused, it may be subject to the procedures provided by the law. An economic power must be considered preponderant when it is strong enough to determine by itself industrial or commercial policy and prices in a given market. "It is necessary . . . that the person in question . . . dominate the market to such a degree that by his own decisions he can guide, balance, or unbalance this market. . . ." 20

20 [1958-59] Documents Parlementaires, Sénat, No. 216, at 10-12. 
It will be more difficult to isolate specific enterprises whose economic power is preponderant than it is to define this concept in the abstract. Only economic market research in every case will suffice. ${ }^{21}$ But meaningful research of this sort is difficult to perform. Within the framework of the Belgian antitrust law, it would be inadequate to rate the influence of an economic unit in terms of production, since much of its output may be for export and hence not covered by the law. Consequently, influence on the market will generally have to be analyzed at the consumer level.

Economic power may be defined either according to the form it takes-monopoly, trust, cartel, pool, konzern, holding-or, rejecting formal criteria, according to its effects. The new Belgian law, unlike most of its foreign counterparts, uses the latter method. Once the decision was made to direct the statute toward the repression of abuses and not toward a system of interdiction, this choice was quite logical: abuses occur in the manifestations of economic power on the market, not a priori in its form. Consequently economic power, as defined in article one, may be a monopoly or any kind of economic integration or cooperation - vertical or horizontal integrations, technical accords, commercial alliances, gentlemen's agreements, or holding companies. This enumeration is not exhaustive and does not itself appear on the face of the section defining economic power for the statute: Parliament was apprehensive that an enumeration of forms would permit certain persons and groups which it intended to reach to slip through the interstices. Consequently any form of economic organization comes within the purview of the law when its influence becomes abusive.

The failure of the Belgian law to distinguish between monopolies and cartels deserves special attention, since foreign laws generally make this distinction. For example, the first section of the Sherman Act ${ }^{22}$ is devoted to cartels and the second to monopolies; ${ }^{23}$ the latter section was written and long interpreted by American courts to treat monopolies less severely than cartels. Stress was laid upon the intention to monopolize a market, while a monopoly created by outside circumstances was not per se illegal. ${ }^{24}$ Recently, however, the courts seem to be scrutinizing more carefully the behavior of enterprises whose size alone implies monopoly power. ${ }^{25}$ The European Coal and Steel Com-

\section{Ibid.}

2226 Stat. 209 (1890), as amended, 15 U.S.C. $\$ 1$ (1958).

2326 Stat. 209 (1890), as amended, 15 U.S.C. $\$ 2$ (1958).

24 United States v. United States Steel Corp., 251 U.S. 417, 449-52 (1920); United States v. Aluminum Co. of America, 148 F.2d 416, 429-30 (2d Cir. 1945) (L. Hand, J.) (dictum).

25 Schwartz, New Approaches to the Control of Oligopoly, 109 U. PA. L. REv. 31, 36-39 (1960). 
munity and the Common Market Treaties also distinguish monopolies from cartels, and strike at monopolies less harshly than at cartels. ${ }^{26}$ Perhaps this is so because it is usually considered that cartels impede progress whereas concentration favors economic development. Once Parliament had chosen to condemn only abuses, there was no need to make this distinction, for it does not matter whether an abuse comes from a monopoly or a cartel. It is possible, of course, that monopolies will call for less frequent applications of the statute than will cartels. Time will tell.

It must be remembered that the new Belgian law originated to counterpoise the royal decree of 1935 on compulsory cartels. Cartels are not made illegal per se, and some are even compulsory in whole branches of the economy by virtue of royal decrees. ${ }^{27}$ But there is no contradiction between the new law and the existence of government-sanctioned cartels: the only groups which may take advantage of the decree are those consistent with the public interest, and the sanctions of the 1960 law apply only to cartels whose activities are inconsistent with that interest. The same criterion, the public interest, approves the former and condemns the latter.

\section{Persons Encompassed by the Law}

Article one is aimed expressly and indiscriminately at natural and legal persons. Any individual or corporate body entitled to legal rights may come within its purview. Associations with no legal existence, such as cartels, are subject to the law as "group[s] of . . . persons acting in concert"; and their officers are responsible for the actions of the groups they direct. This raises a question as to the law's application to commercial groups acting without previous agreement. In American Tobacco Co. v. United States, ${ }^{28}$ the United States Supreme Court held that the existence of collusion could be inferred from the price-parallelism of the big three cigarette manufacturers, without the necessity of establishing an express accord among the "conspirators." The Belgian law gives no precise solution to this question, but it seems unlikely that it will be read to permit the inference of a concerted common purpose from the mere existence of identical behavior by several enterprises.

An important, but temporary exception to the law's application concerns government-controlled institutions, including provincial and

26 Compare Treaty Establishing the European Coal and Steel Community, April 18, 1951, art. 65, with id., art. 66. Compare Treaty Establishing the European Economic Community, March 25, 1957, art. 85, with id., art 86.

27 There are now compulsory cartels in only three sectors of the economywindow panes, glazier's putty, and floor coverings.

28328 U.S. 781 (1946). 
local authorities. ${ }^{29}$ The theory of this exemption was that these institutions are already subject to the public interest. Nevertheless, the exception is regrettable. The public sector of the Belgian economy is highly developed. The government is an entrepreneur in entertainment, controlling the radio and television networks, in transportation, with the railroad monopoly and airlines control, in banking, through various credit institutions, and in insurance, by securing export risks. The government also monopolizes the telephone and telegraph industries. The economic power of the state as a buyer comes close to monopsony in the market for goods used only by state-controlled enterprises. Within the range of these industrial, commercial, and financial activities the state may represent a preponderant economic power in several markets, and could abuse this power by restrictive or discriminatory practices. Frequently, public service industries indulge in price discrimination, grant rebates, impose tariffs, or exact fidelity or exclusivity contracts. It would be normal for the law to reach these state activities, as do the provisions on competition in the Common Market and the Coal and Steel Community Treaties. ${ }^{30}$ Moreover, while it is proper in considering the so-called traditional functions of the state to ask whether the state, which defines the public interest, can hurt it, the question raises no paradox when applied to the activities just mentioned. These public services enjoy a large managerial autonomy; their conduct takes its example from the practices of private enterprise. It follows that they should be submitted to the same limitations in the exercise of their economic power.

However, the exemption of government enterprises is only temporary. Article 27 of the law provides that within five years-before June 1965-the law will be applied to these activities by royal decree. The decree will be permitted to apply different procedural provisions to government enterprises from those pertaining to the private sector, but the definitions of preponderant economic power and abuse may not be altered.

\section{Enterprises Covered by the Act}

The enumerated activities liable to give rise to abuses cognizable under the new law are industrial and agricultural production, distribution, and finance. The last term is aimed at holding companies able to exert a preponderant influence on a given market through subsidiaries. The liberal professions and athletic, philanthropic, religious, political, and social groups are not subject to the act, even though any

29 The exception was conceded by the Government to disarm the Socialist opposition, and win its support for the legislation.

30 Treaty Establishing the European Economic Community, March 25, 1957, art. 90; Treaty Establishing the European Coal and Steel Community, art. 66. 
of these may have a considerable influence on the nation's economy. One consequence is that labor unions are not covered, for their activities are thought to be of a social nature and not to belong to the categories listed in article one. The wisdom of this exception is doubtful. The ability of labor unions to order strikes is an unquestioned economic power which can be subject to abuse. However, the parliamentary debates make it clear that the statute was not intended to be applicable to labor unions.

Within the framework of the enumerated activities, economic power must exert its preponderant influence on supplying the market for commodities or capital or on the price or quality of a given commodity or service. ${ }^{31}$ The law aims at the supply of goods to the market as well as the price and quality of goods supplied. A difficulty familiar to economists arises in trying to delimit a relevant market. A market may be defined with reference to a broad category of products or limited to a specific product. According to the choice made, the importance of the leading enterprise in the market will appear very different. $^{32}$

\section{Geographic Scope}

The nationality of the person who wields economic power is unimportant. His activities violate the law as soon as they exert a preponderant influence in Belgium. The classical rules of conflicts of law as to legislative jurisdiction are pushed aside by this act pertaining to Belgian "public policy." It applies to any abusive manifestation of economic power within the kingdom. However, this statement is merely academic if the headquarters of an economic power and all of its property are situated in another country. Enforcement action based exclusively upon Belgian law would be completely ineffectual in such a case.

Export cartels may come within the scope of the 1960 law if they have a preponderant influence in Belgium, for instance, by undermining the supply of goods in national markets.

\section{The Abuse of Preponderant Economic Power}

Article two of the law defines the abuse of economic power as harming the public interest through restrictive practices. No enumeration of specifically outlawed practices is included in this section. ${ }^{33}$ As

31 The language of article one indicates that dealings with real property are not subject to the act.

32 For an American example, see United States v. E. I. Du Pont de Nemours \& Co., 351 U.S. 377, 394404 (1956).

33 A proposal to enumerate in article one certain practices apt to harm the public interest by distorting the normal course of competition was rejected in order to avoid any presumption that these practices are necessarily abusive. Nevertheless, a list 
the normal corollary of such a broad definition, each situation must be separately and profoundly studied, both to determine the existence of a preponderant economic power and to detect abuses. ${ }^{34}$ Unquestionably, the new law will be administered on a case-by-case basis. The statute, like the Sherman Act, was written in general terms in order to create a wide field of application and to give the competent authorities a chance to appraise a large number of cases. Experience may show the need for further legislation which, like the Clayton Act, will be more specific.

\section{Injury to the Public Interest}

A preponderant economic power is abused only insofar as it harms the public interest. A political concept, the public interest changes according to the orientation of economic policy at the moment, the structure of the economy, and the ends which the nation wants to attain. As a consequence, it is difficult, if not impossible, to define or even describe it adequately. The Minister of Economic Affairs confessed this difficulty to the Senate, but added, "I think I may say, in a rather elementary way, that the public interest is the defense of the collective interest, in opposition to the defense of individual interests which could sometimes be in contradiction to the interest of the whole of the collectivity . . . " 35 As the public interest follows the fundamental necessities of the national economy over the years, it may disaccord with individual interests, even of important groups or broad segments of the population. The public interest is not necessarily the interest of consumers, although a certain tendency appeared during the drafting of the law to consider its principal aim as protecting consumers against the price manifestations of monopoly. But the legislative dictate is to examine each case with due consideration to all affected interests. No group, such as producers or distributors, may be systematically neglected. It is necessary to consider the rights of the various professions, to weigh the conflicts of interests between different industrial sectors, and, on a broader level, between the different branches of the economy. Each class of society may feel the effects of a given situation or practice in a different way.

was contained in the "statement of grounds," a document customarily given to members of the Belgian Parliament together with a bill to explain the proposed legislation. Statements of grounds have no legal effect, but they are frequently relied upon to clarify ambiguous statutory language.

34 Several members of Parliament asked the Minister of Economic Affairs to decide whether there were abuses in various hypothetical cases. The Minister declined to answer, saying, "the investigation [in each case] will reveal whether or not specific practices are opposed to the public interest." [1959-60] Documents ParlementaIres, SENat, No. 36, at 5.

35 Annales Parlementaires, Senat, Dec. 18, 1959, at 143. 
It should be noted that commercial restrictions can favor the stability of employment whereas free competition may multiply business failures. Finally, an expanding volume of international trade may justify some practices which would seem undesirable in a strictly national context.

\section{Restrictions on the Normal Course of Competition}

As part of its definition of abuse of preponderant economic power, article two mentions "practices which distort the normal course of competition." That phrase, borrowed from article 65 of the treaty creating the European Coal and Steel Community, ${ }^{36}$ raises many questions relating to economic theory.

The competitive structures of markets have been the subject of an abundant economic literature, especially since two works by Professor Chamberlin ${ }^{37}$ and Mrs. Robinson ${ }^{38}$ dealt a decisive blow to the classical theory built on the hypothesis of perfect competition. Perfect competition does not exist. It is a useful but oversimplified model for commencing the study of market functioning but which must be passed in order to reach economic reality. Almost the same objection can be made to the hypothesis of monopoly, which is found in its pure state only under exceptional circumstances. Actual market structures are either imperfect states of competition, lacking some of the classical conditions of perfect competition, or monopolistic competition, which, according to Professor Chamberlin, has features of both monopoly and competition, each seller holding a kind of monopoly because of product differentiation, but each aware of potential competition from other products which could be substituted for his own should his prices climb too high. Further economic reseach has defined a large number of other market structures according to many criteria.

It would be fatuous to try to legislate "perfect competition" into existence. The Belgian Parliament certainly did not try to do this, as is shown by its continued approval of certain "imperfect" elements in the nation's competitive structure, such as the decree on compulsory cartels. Some deviations from unlimited competition are desirable for Belgium's economic health. For example, it would be nonsense to insist that electric power companies compete for customers, and to forbid liaison and cooperation between them. ${ }^{39}$ Similarly, unbounded competition would

36 April 18, 1951. It is interesting to note that this article was drafted by a group of American lawyers. Compare similar language in the Treaty Establishing the European Economic Community, March 25, 1957, art 85.

37 Chamberlin, The Theory of Monopolistic Competition (1933).

38 Robinson, The Economics of Imperfect Competition (1933).

39 Reuter, A Propos des Ententes Industrielles et Commerciales, [1952] Drort SOCIAL $442-47$. 
be harmful in the coal industry, where constant supply confronts a variable demand. Moreover, the structure of the Belgian economy in the face of foreign competition requires some forms of cooperation between economic units, in spite of the restrictions on competition which may result. Yet another justification of commercial restrictions is pointed out in a recent decision of the Cour de Cassation ${ }^{40}$ refusing to condemn a boycott of a druggist who sold pharmaceutical products at prices lower than those fixed by a price cartel of pharmaceutical specialties. The court held that "free competition is not an absolute right, but is limited by the existence of equal rights for other people. The exercise of these rights by a group cannot constitute a fault once it has been established . . . that this cartel defends the legitimate interests of the group by protecting itself against falling prices in order to maintain both the quality of the product and the proper remuneration of the profession." Finally, and more generally, it would be paradoxical to impose the model of perfect competition on the nation's economy by means of a law whose proclaimed purpose is to strengthen economic freedom.

What meaning, then, is to be ascribed to the phrase "normal course of competition"? It is not borrowed from economic theory, the function of which is to describe and explain. For, we have seen that economic theory has isolated a number of competitive structures none of which is a priori more "normal" than others. Normality imports a value judgment on existing economic facts. In the context of an antitrust law, it also imports an economic policy-an attempt to influence economic conditions by perpetuating them in the face of changing circumstances or altering them according to some preconceived plan. An antitrust law is an instrument of economic policy designed to protect a competitive order which the state considers necessary for the welfare of the national economy. Certainly the Belgian law comes within this description by defining "abuse" as a harm done to the public interest. Such harm must manifest itself by interfering with the normal course of competition. The term "normal" is pregnant with economic policy. The normal course of competition is not a fact; it is nothing more than the degree of competition considered desirable. The problem of economic policy, and the key to understanding the term "normal," lies in describing the characteristics of the type of competition which is desired rather than those created by the spontaneous intercourse of ideal economic mechanisms. Competition is not a selfsufficient end, but a means toward a desired result which must be

40 Judgment of June 2, 1960, [1960] 1 Pasicrisie, 1133 (Bel.). Roughly, the Contr de Cassation is Belgium's supreme court. 
articulated by fundamentally political institutions. Their choice, expressed in terms of their conception of the best working of the economy and the growth of the national welfare, will determine the "normal course of competition."

\section{Procedure}

Whereas the first two articles of the new Belgian antitrust law purposely define its scope very broadly, the fifteen articles which follow set forth detailed procedures for its enforcement. There are three main stages involving three competent authorities. Preliminary investigations and hearings to discover abuses of economic power are conducted by the commissaire-rapporteur, a magistrate appointed by the King from among the public prosecutors who have been in office at least five years. The commissaire's affirmative findings of abuse are reviewed by the Conseil du Contentieux Economique, an institution created in 1935 to hear requests for the establishment of compulsory cartels in various branches of the economy. Since the 1960 law is considered a counterpart of the 1935 decree and the criterion to be applied-the public interest-is the same, it was thought logical to give the Conseil jurisdiction over cases concerning the abuse of economic power. The Conseil is composed of a president, a vice-president, and six members, all appointed by the King from the judiciary. Like the commissaire they are magistrates and remain subject to judicial discipline. Cases in which the Conseil affirms the commissaire's findings of abuse are referred with the Conseil's recommendations to the Minister of Economic Affairs, who may negotiate, conciliate, and, finally, coerce the implicated parties to end their abusive practices.

\section{Proceedings Before the Commissaire-Rapporteur}

The commissaire-rapporteur is in charge of turning up abuses of economic power. In any case he may use either of two procedures, a hearing (information) or an investigation (instruction). He starts the hearing procedure sua sponte or at the request of the Minister when there are serious indications of an abuse of economic power in a given market. In the course of the hearing the commissaire-rapporteur may call for "any information fit to enlighten him" and hear "all persons likely to provide him with useful information," but he has no power to compel testimony or the production of documents. He reports the results of a hearing to the Minister.

The investigation is a more elaborate procedure undertaken at the suggestion of the Minister of Economic Affairs or on the complaint of "any natural or legal persons or of organizations representing common interests, harmed by practices falling under article two." The 
commissaire-rapporteur may decline to investigate any complaint which is groundless on its face if he informs the Minister and the complainants of the reasons for his decision. Parliament granted this preliminary sifting power in order to compensate for its liberality in permitting private individuals and groups such as trade associations, labor unions, and consumers' organizations to lodge complaints. If he accepts a complaint, the commissaire-rapporteur proceeds with the investigation itself, for which he is armed with important powers to facilitate collecting all the information and documents he considers useful. He may gather evidence, resort to experts, and, within limits, conduct searches. The commissaire's deputies and other government agents assist in conducting an investigation. At the end of this procedure the commissaire-rapporteur formally decides either to drop the case or to forward it to the Conseil du Contentieux Economique. If he drops the case, he must inform the Minister, who may, within thirty days, overrule the commissaire's decision and continue the proceedings by referring the case to the Conseil. If the Minister accepts the commissaire's decision, the complainant and the implicated parties are notified. Any case undertaken at the Minister's behest may be discontinued by the commissaire-rapporteur after investigation. If the commissaire considers the case proper to forward to the Conseil $d u$ Contentieux Economique, the case enters the second procedural phase.

\section{Proceedings Before the Conseil du Contentieux Economique}

The Conseil de Contentieux Economique takes jurisdiction when the commissaire-rapporteur files the dossier at the Conseil's secretariat, or when the Minister reports a case in which he has rejected the commissaire's negative decision. The parties are informed that their case has been forwarded to the Conseil and of the date on which a hearing is scheduled. In the meantime they may consult the dossier and file briefs supporting their arguments.

The procedure before the Conseil is mainly written, although there is a hearing at which the Conseil listens to the parties or their representatives, to the commissaire-rapporteur, who may have been asked to make further inquiries, and to the complainants, if the Conseil finds it expedient to invite them. In addition, the Conseil is assisted by four experts in the field of economics who give their written opinions and take part in the debates, but do not vote. For each case, the experts are chosen by the Conseil from lists prepared by the Conseil Central de l'Economie and the Minister of Economic Affairs. The proceedings are closed to the public since "there are trade secrets, commercial devices, and sometimes even information of a diplomatic or political 
nature whose utility could be injured by publicity." ${ }^{41}$ The opinion of the Conseil is published only if conciliation by the Minister fails and it is necessary to issue a royal decree in order to end the abuse.

The expenses of the proceedings are normally borne by the state: even though an abuse is established it is not a criminal offense. Besides, it makes sense that the state should undertake the cost of maintaining the competitive order which it has adopted to further its economic policy. Nevertheless, the law provides that the King may "recover the expenses."

The Conseil finishes its task by preparing a formal opinion. In it the Conseil analyzes the "economic balance sheet" by weighing all the factual elements in the case to determine whether the implicated persons or group represents a preponderant economic power in a relevant market, and whether the practice restricting the normal course of competition with which they are charged harms the public interest. The opinion is handed to the Minister of Economic Affairs, the implicated parties, and whoever filed the complaint. If it states that there is no abuse, the case is closed and the Conseil's decision binds the Minister. If, on the other hand, the opinion affirms that there is an abuse of economic power, it is accompanied by recommendations to end the abuse, and the third stage of the proceedings begins.

\section{Proceedings Before the Minister of Economic Affairs}

Although the Minister is bound by a decision of the Conseil du Contentieux Economique that there is no abuse, if the Conseil's opinion is affirmative, the Minister is free to reject its conclusions. However, this alternative seems rather academic; in the large majority of cases the Minister will probably accept the findings of the Conseil without necessarily adopting all of its remedial proposals.

The proceedings before the Minister start with conciliation. It is hoped that all cases will be solved at that stage, making it unnecessary to resort to coercion. The Minister or his deputy summons the persons involved, listens to their observations, and suggests ways to end the abuse. If his recommendations are accepted, the agreement is recorded and the Moniteur belge publishes a notice that the case is closed, without revealing the contents of the agreement. ${ }^{42}$ The parties are pledged to fulfill the agreement reached with the Minister. If they

41 Verhaegen, [1947] Journal Des Tribunaux 534.

42 The conciliation practice has some resemblance to consent decrees which conclude many antitrust actions in the United States. However, the bargaining power of companies under investigation is not as strong in Belgium as in America, since negotiations take place before the Minister, who personally holds coercive power should efforts at conciliation fail. In the United States most compromises are sought before the Federal Trade Commission, but it is the judiciary which decides upon compulsory measures if no compromise is reached. 
do not, the Minister directly submits a decree to the King, bypassing the second stage of the proceedings, that of mandatory recommendations. Indeed, that phase of proceedings before the Minister takes place only when conciliation has failed. In such a case the Minister orders the parties to effect his recommendations within a specified time, giving them a final chance to end the abuse voluntarily.

If the persons whose activities were investigated do not respect the conciliation agreement or do not obey a ministerial order after conciliation has failed, the Minister asks the King to issue a decree stating the existence of the abuse and ordering measures necessary to end it within a given time. The parties are notified of the royal decree which is published in the Moniteur belge along with the original opinion written by the Conseil du Contentieux Economique.

There has been some dispute over the measures which a royal decree may order in these cases. The "statement of grounds" 43 simply mentions "adequate" measures and explains its laconism as necessary "to enable the executive to evaluate the sanctions in the best way for all concerned, having regard to the seriousness of the various offenses." 44 Yet some contend that a royal decree may only interdict-that it may not order the performance of affirmative acts. ${ }^{45}$ However, the principles of an abuse system do not compel this conclusion; although no specific practices are made a priori illegal, once it is established that a business has been guilty of abusive behavior in the whole course of its conduct, the executive may well point to specific acts whose omission stands in the way of ending the abuse. It follows that the decree should be able to order all that is necessary to put an end to the abuse, no matter whether these injunctions are negative or positive.

The law does provide for severe measures against corporations guilty of further abuses after having been the object of a royal decree or a ministerial order. These sanctions are intended to go beyond eliminating abuses and attack the maleficent economic power itself. The King may prohibit mergers and interlocking directorates, forbid one company from acquiring shares in another, and even order the sale of certain holdings. ${ }^{48}$

43 See note 33 supra.

44 [1958-59] Documents Parlementaires, Sénat, No. 216, at 22.

45 Annales Parlementaires, Chambre, May 18, 1960, at 4.

46 The last sanction is inspired by United States practice. See United States v. Paramount Pictures, Inc., 334 U.S. 131, 150-53 (1948); Standard Oil Co. v. United States, 221 U.S. 1, 77-79 (1911); cf. United States v. E. I. Du Pont de Nemours \& Co., 177 F. Supp. 1 (N.D. I11. 1959), prob. juris. noted, 362 U.S. 986 (1960) (No. 781, 1959 Term; renumbered No. 55, 1960 Term). 
At the end of three years a person who has been subjected to ministerial compulsion or a royal decree is entitled to an official announcement that the abuse has ceased.

The fact that enforcement of the Belgian antitrust law is placed in the hands of the executive, in contrast to the situation in the United States where only the courts are empowered to order coercive measures against restrictive practices, bears comment. The Belgian solution is based on the understanding that "abuse" is defined as doing harm to the public interest-a concept filled with the basic aims of the nation's economic policy. It was logical for Parliament to vest coercive power in the executive branch since it is the one to define and realize this policy as part of its program of overall economic planning. Nevertheless, this choice elicited much controversy during the drafting of the statute. One suggestion was to empower the Cours d'Appel, judicial bodies, to determine abuses of economic power; but the Conseil d'Etat ${ }^{47}$ opposed this plan as contrary to the principle of separation of powers, since the criterion of abuse is the public interest. Other opponents of the suggestion pointed to the danger of contradictory court decisions, the incompetence of judges on economic matters, and the need to make Belgian law consistent with that of other Common Market nations. In reality the final solution does not leave much room for arbitrary executive enforcement. The commissaire-rapporteur, appointed by the King from among the public prosecutors, is really not a representative of the executive and is largely independent of the Minister of Economic Affairs. The commissaire's only obligations to the executive are to commence proceedings at the Minister's request and to notify him if the hearing procedure is to be initiated or a case is to be dropped after an investigation. Moreover, only judges may vote in the Conseil $d u$ Contentieux Economique, and their negative opinion terminates any proceedings under the act, while their affirmative conclusions are merely the basis for further proceedings. The phase of negotiation and conciliation before the Minister should solve most cases by consent, leaving only a persistent few to the compulsory orders provided by law. Finally, ordinary courts still have their full prior competence despite the law of May 27, 1960.

\section{Penal Sanctions}

Neither economic power nor its abuse is criminal; however, violation of a decree ordering the end of an abuse is a crime which may be

47 The Conseil d'Etat is a dual institution: an administrative section hears appeals from administrative decisions; a legislative section given advisory opinions on proposed legislation. 
punished by eight days' to one year's imprisonment and a fine of from 10,000 to $1,000,000$ francs. ${ }^{48}$ Penalties are higher for violating a royal decree directed toward a subsequent abuse and for committing an abuse within five years after having failed to end a prior abuse during the required period. It is also a crime to interfere with the conduct of investigations by the commissaire-rapporteur or to give false statements to him. Organizations with legal personality are liable for fines incurred by the misdemeanors of their agents, whereas unincorporated associations will probably be punished through their officers.

\section{Judicial Competence Under Prior Laws}

Even before the adoption of the 1960 law on the abuse of economic power there were some legal devices for controlling restrictive practices in Belgium. ${ }^{49}$ The 1960 act fills significant gaps in the old laws which permitted many grave abuses to go untouched. But it does not repeal the former laws nor the competence of the ordinary courts. The cases selected by the commissaire-rapporteur for submission to the Conseil du Contentieux Economique are only those which raise questions of the public interest. The judiciary retains exclusive jurisdiction to protect private rights and may even adjudicate the private aspects of disputes which might fall under the new law. However, it is likely that where a choice is available, aggrieved parties will prefer the procedure afforded by the new act for its expedition and economy. On the other hand, where pecuniary damages are sought, it will be necessary to resort to ordinary litigation.

\section{Appeals}

As a rule, only final decisions may be appealed. The Minister may thus appeal from a negative opinion by the Conseil $d u$ Contentieux Economique to the administrative section of the Conseil d'Etat. Likewise a royal decree ordering the termination of an abuse may be appealed to the same judicial body. Royal decrees which go beyond the authority conferred on the executive are subject to collateral attack under article 107 of the Constitution, which directs courts to refuse enforcement to royal decrees they consider illegal.

\section{Conflict of Laws: The European Treaties}

As the importance of European national borders recedes and economic units distend among the nations, it is reasonable to suppose 
that the principal antitrust problems of the next few years will concern international law rather than the Belgian law of May 27, 1960. It is nevertheless important to solve the problems of construction and reconciliation between the national and international laws.

The Treaty Establishing the European Coal and Steel Community, signed by six countries, adopts an interdiction system as to cartels $^{50}$ (with certain exceptions) and an abuse system combined with a requirement of prior authorization as to concentrations. ${ }^{51}$ In case of an inconsistency between Belgian law and the treaty, with reference to any enterprise which is subject to both, ${ }^{52}$ the treaty undoubtedly must control. Indeed, the statement of grounds appended to the new Belgian act confirms that "the present bill does not limit [Belgium's approval of] . . . the Treaty Establishing the Coal and Steel Community." 53

Reconciling the antitrust law contained in the Treaty Establishing the European Economic Community (Common Market) is more delicate. Articles 85 and 86 forbid cartels, with certain exceptions, and repress abuses of concentration insofar as they affect trade between member-nations. Article 87 provides that the EEC Council will promulgate "all useful regulations or recommendations for the application of the principles expressed by articles 85 and 86." From this language it has been argued that the preceding two articles are not self-executing, but are merely to guide the drafting of national statutes. The adoption of regulations under article 87 should render this controversy moot; but early in 1961 they were still being prepared. Meanwhile, Belgium has followed the requirements of article 88 of the treaty, which directs that until article 87 regulations come into force, the individual member nations are to decide on the admission of cartels and the misuse of economic hegemony in the Common Market. The new Belgian act applies its own procedure to cases arising under the Common Market, but the substantive law of the treaty, which forbids cartels and condemns abuses of concentration.

\section{ConcLuston}

The Belgian law of May 27, 1960, must be considered in light of the circumstances which necessitated it and the framework in which art. 65

50 Treaty Establishing the European Coal and Steel Community, April 18, 1951,

51 Treaty Establishing the European Coal and Steel Community, April 18, 1951, art. 66.

62 The enterprises subject to the provisions of the Treaty Establishing the European Coal and Steel Community are defined in article 80 of the treaty.

53 [1957-58] Documents Parlementaires, Chambre, No. 21, at 20 . See also note 33 supra for the function of a "statement of grounds." 
it was born. The crises of the Thirties, postwar economic realignments, and the opening of the Common Market each pointed up the need for rationalizing the Belgian economy by permitting enterprises to cooperate among themselves. Several laws, especially fiscal measures, favored mergers and concentrations. But this commendable evolution, insofar as it restricts competition on the market, is contrary to Belgium's economic policy, which favors the conditions of a market economy and requires, among other things, maintaining a competitive order. It thus became necessary to set some limits on restrictive practices which are otherwise encouraged. The Belgian Parliament compromised between these contrary exigencies by encouraging economic power, the generator of efficiency and progress, and punishing its abuses-by protecting competition, the source of initiative, but only within the limits of a workable competition.

The Belgian antitrust law, like those in force in other European countries, ${ }^{54}$ is conceived differently from that which prevails in the United States. Although American law admits some flexibility, ${ }^{65}$ it is fundamentally interdictive, declaring many practices illegal per se. ${ }^{58}$ Another important difference between recent European antitrust legislation, which Belgium's new statute typifies, and American law is that the European statutes partake of the whole economic policy of these nations. The general reorganization following two world wars induced public authorities in the Old World to follow a comprehensive program of intervention in the economy. Some countries, like Sweden, adopted socialistic regimes, while the majority embraced a neo-liberal political philosophy which vests in the state a major responsibility for ameliorating economic and social conditions. L'intérêt général, whose injury by a preponderant economic power constitutes an abuse, is a concept belonging to the public law. The corresponding private law concept is l'ordre public. Both concepts are at the same time rich and variable in their contents. But the judiciary decides questions affecting l'ordre public, while the executive fosters l'intérêt général, since it is defined to include the basic aims of the nation's policy at any particular moment. Consequently most European antitrust laws are applied by the executive, while the emphasis in the United States is more upon judicial enforcement.

54 See also Law of June 28, 1956, "on economic competition," [1956] STAATSBLAD VAN HET KRONINKRIJK DER NEDERLANDEN 401 (Neth.); [1958] STAATSBLAD VAN HET KroNINKRIJK DER NEDERLANDEN 412 (Neth.).

55 E.g., "the rule of reason," United States v. American Tobacco Co., 221 U.S. 106, 178-80 (1911) ; Standard Oil Co. v. United States, 221 U.S. 1, 59-60 (1911).

56 See, e.g., United States v. Trenton Potteries Co., 273 U.S. 392, 396-401 (1927) (price fixing agreements). 
The Belgian law on the protection against the abuse of economic power is a new tool. The legislative task is over, but a protracted social evolution has begun. Belgian businessmen, too long worried about the conceded need for rationalizing the nation's economy, must learn about the important role which competition may play in Belgium's economic and social growth. On the other side, those responsible for applying the new law will need to feel the delicacy with which their job of education, control, and repression must be carried out, with the knowledge that they share in a genuine economic magistracy. Economists and lawyers will now need to work together in trying to understand the impact and application of this new mechanism for public regulation of the economy.

The law of May 27, 1960, Belgium's first attempt to regulate restrictive practices and economic concentration, is an experiment. Its careful preparation and generally favorable welcome augur well for its satisfactory adaptation to the nation's social and economic institutions. Only experience will demonstrate whether this law will insure Belgium the reign of a truly competitive order, which supports a healthy free enterprise system, and constitutes a major element in the organization of the Western World. 